\title{
Parenting Styles of Single Parents for Social Emotional Development of Children at Early Childhood
}

\author{
Gunarti Dwi Lestaria ${ }^{a}$, Rezka Arina Rahma $^{\mathrm{b}}$ \\ Nonformal Education Department, Universitas Negeri Surabaya \\ Surabaya, Indonesia \\ Corresponding e-mail: agunartilestari@unesa.ac.id, brezka.arina@gmail.com
}

\begin{abstract}
Parenting styles is children nurturing process by a technique focused on giving affection as a deep supervision from parents to children. The objective of this research is to investigate the parenting method of single parents to children at early childhood taken care of by single parents. The methodology of this research is qualitative descriptive. The data was collected by interviews, observations and documentations. The results show that the parenting styles characteristics of single parents are: a) giving freedom, yet responsible b) blame the children, if they did wrong c) giving boundaries about do's and don'ts. In the other side, social emotional development of children at early age with single parents proved with some behaviors as: 1) get mad if something doesn't happen as they will. 2) shared voluntarily to friends 3 ) not being shy if they asked to shake hands 4) if someone talk to them, they answered.
\end{abstract}

Keywords: parenting styles of single parents, social emotional development

\section{INTRODUCTION}

Family is the smallest social circle that has important role as the first environment recognized by children and character builder. Children in the early stage of development will receive stimulation from family environment. Bronfonbenner (2009) in ecological system theory stated that family environment is called microsystem environment. This environment provides a very strong influence in shaping children's personality.

In this stage, children need parents' roles and environment's response to strengthen their behavior. Twoparent family (father and mother) is needed to help children to own and develop the basics of self-discipline (Shochib, 2010:18). If a child is raised by a single parent, the absence of a father or mother in the family makes the child less attentive and get neglected.

A child who is raised by two parents will tend to develop into a stronger child, has better emotional control and self-reliance behavior compared to a child from broken home. In a family, a father plays role as: (1) facility provider or giver; (2) protector; (3) decision maker; (4) child educator who provides social education; (5) nurtured mother or mother's companion (Dagun, 2002:2-17).

Alexander A. Schneider in Yusuf (2004:43) explained that an ideal family has characteristics as follows: (a) lower frequency of disputes between parents or parents and children; (b) members of the family have the opportunity to express their opinions and wishes; (c) members of the family show affection towards each other; (d) parents never use anger and punishment as discipline method; (e) children have opportunity to be independent in thinking, feeling and behaving; (f) there is mutual respect between parents and children; (g) family use discussion as problemsolving method; (h) there is good cooperation between parents and children; (i) parents have more stable emotion; (j) being economically established; and $(\mathrm{k})$ family believe in religion and moral values. If family could not apply or carry out one of the characteristics above, it means that they have family dysfunction which can lead to the broken of family relationship and disruption of children development.

Socio-emotional intelligence refers to the abilities of self-control, self-motivation, empathy, and ability to connect with the environment. Emotional intelligence also plays important role in building individual success. Children's socioemotional intelligence can develop optimally if the obtained stimulation is in accordance with its development. Parenting style adopted by parents has a great influence on the development of children in their early stages. In a family who uses authoritative parenting style, children will tend to be less communicative than those who grow up in a democratic family. In an authoritarian family, children are restricted to express their opinions, while in democratic family, children are encouraged to express their opinions and participate in family conversations (Hurlock, 1995:190).

This research was conducted on Madurese who live in Kampung Sombo, Sidotopo, Semampir, Surabaya. This is an area where most of its 
inhabitants come from Madura. Madurese women, especially those who are single parents, have problems in raising their children. The problems are generally derived from social and cultural changes in Madurese society that impact the community's attitude and mindset. As a result, the problems can affect parenting style.

In accordance with the problems above, it is very important to conduct further research on Single Parents' Parenting Style for Children's Socio-Emotional Development at Early Ages in Sidotopo, Surabaya, by taking a research focus on:

1. How is the parenting style adopted by Madurese single parents in Sidotopo, Surabaya?

2. How is children's socio-emotional development at early ages who are raised by Madurese single parents in Sidotopo, Surabaya?

\section{RESEARCH METHODS}

In this research, the author employed qualitative approach to analyze the problems. The objects for this research were two single parent mothers who have children at early ages. The first informant (Informant I) is Mrs. Misnatun who has two children named Dian (13 years old) and Toha (3 years and 3 months old). She becomes a single parent because her husband has died. The second informant (Informant II) is Mrs. Salamah who has one daughter, Khoirunnisa (4 years and 4 months old). She becomes a single parent because she divorced her husband.

There were several data collection methods as follows:

\section{Participant observation}

This method was employed to find parenting style adopted by single parent mothers in Sidotopo. Using this method, the obtained data could be accounted and the author could communicate directly with the informants to ask questions more detail regarding to the research.

\section{Interview}

The researcher used written interview to get honest answer from the participants. The participants were expected to provide honest answers so that the information provided would be in accordance with the research focus. The researcher interviewed two single parents and their respective extended families. In addition, interview was conducted with one neighbor of each parent who live in Sidotopo.

\section{Documentation}

In this method, the researcher made a check-list of predefined variables of documentation. The method was carried out by taking notes, photos and videos of the activities happened in the location.

\section{RESULT AND DISCUSSION}

Based on the findings of the study, an analysis was conducted to describe the parenting styles and the socioemotional development of children at early ages raised by single parent in Sidotopo. The analysis and discussion are explained in the following paragraphs:

\subsection{Single Parent's Parenting Styles}

The parenting style in this study is related to the followings: (a) provision of punishment, (b) single parent's involvement in children's activities, (c) relatives' roles in assisting single parent in parenting. The followings are the description of the two informants' daily activity:

\section{a) Provision of punishment}

Punishment is given by parents to their children when children make mistakes or violate the rules that have been arranged by the mother. Punishment is given because as a parent, especially a single parent, mother has an important role to educate her children since early ages, and the punishment is considered necessary to be given in order to make the children get accustomed to act accordingly to the rules, either within the family or community. In the present study, Informant I states that she gives a punishment to her children in the form of reprimands and physical punishment such as pinching and twisting the children's ear. While for Informant II, in giving punishment, she claims that she also gives verbal punishment in the form of reprimands, advices, eye glares or shouts, as well as physical punishment such as spanking or pinching if the children cannot be controlled anymore.

b) Single parent's involvement in children's activities Parent's (mother) participation in children activities, especially when children are at early ages, is important because they tend to imitate activities performed around them, whether they are good or bad. In other words, the role of mother is to be the best filter for children personality and behavior. For Informant I, she spares some time to watch her youngest daughter playing, learning and doing other activities. Nevertheless, she usually needs her first child's assistance to look after her sibling. Supervision is done by Informant I because according to her statement, she does not want her daughter to play in accordingly to her age. As for Informant II, she also manages to spare her time to accompany her daughter doing 
their activities. Taken as an example, Informant I was waiting for her daughter when playing odong-odong ride when the research was conducted on June 20, 2015. Unlike Informant I, Informant II is available almost every day, caring, nurturing and educating Khoirunnisa without much help from other family members.

c) Relatives' roles in assisting single parent in parenting

There is a similarity of the subjects of the research, in which they rather have big family (extended family), which consists of not only father-mother-children, but also other family members, such as grandparents, uncle and unmarried siblings. In accordance with the opinion of Sudarja and Sigelman (Yusuf, 2004: 36), extended family consists of not only husbands, wives and unmarried children, but also includes relatives and usually live under the same roof, such as mother-/father-in-law, sister/brother-in-law or others, even maids or other people who usually stay within the household.

Both informants have something in common in terms of having extended family. Therefore, there is direct involvement of the extended family in raising the children, either big or small role.

The following characteristics are obtained based on the single parents' daily life at home in raising children in order to shape the children's socioemotional development:

(1) Informant I:
(a) Mother gives daughters freedom with responsibility.

(b) Mother rarely gives physical punishment, such as pinching, when her daughters make mistakes. Instead, the daughters are often given verbal punishment, such as reprimands.

(c) Instead of providing explanations, mother gives prohibitions when her daughters make mistakes.

(d) There is huge frequency of mother's involvement in her daughters' activities, such as looking after them in the middle of her working time.

(e) Mother gives daughter's freedom to get along with their peers, but still in the area of her supervision.

(2) Informant II

(a) Mother rarely gives punishment.

(b) Applying strict limits on the daughter's wills.

(c) Giving daughter freedom to socialize with her peers.

(d) Mother gives explanations about her daughter's mistakes (e) Mother rarely involves in her daughter's activities at home

Parenting style adopted by single parents in Kampung Sombo, Sidotopo, Surabaya, is referring to positive parenting styles. In accordance with the theory used in the study, there are three parenting styles: authoritarian, democratic and permissive. However, the data showed that Informant I is more likely to perform democratic authoritarian, while Informant II perform permissive democratic in her parenting style.

Parenting style adopted by single parents tends to grant freedom to children. Nevertheless, the parents highly engage in their children's activities by monitoring and establishing assertive limitation to not be violated. Findings of parenting style are consistent with Baumrind's theory (Santrock 200:257) which encourages children to work independently, but parents still implement control and regulation upon children's activities. Extensive verbal discussion may be needed, in which parents show their warmth and affection. Furthermore, authoritative style is commonly associated with children's social competence.

Given the evidences and theories, it is assumed that single parents of Madurese migrant groups in Sidotopo, Surabaya are more likely to perform democratic authoritarian style.

The followings are the similarity of democratic parenting style adopted by the single parents:

a) Mothers gives children freedom with responsibility.

b) Mother rarely gives physical punishment, such as pinching, when her children make mistakes. Instead, the children are often given verbal punishment, such as reprimands.

c) Mother fulfills her children's wills, yet give the children clear limitation.

\subsection{The Development of Children's Socio-Emotional at Early Stages Raised by Single Parent}

a) Early Childhood's Social Development with Single Parent

Single parents of Madurese migrant groups in Sidotopo argued that salient indicators of social development outcomes are portrayed in the following experiences: 1) responding to other utterances; 2) happier when interacting with their same-age peers; 3) can imitate words if required; 4) willingly to share own stuff; 5) have no interest in disturbing others; 6) show confidence when being asked for handshake; 7) show reciprocal conversation.

Those given criteria are almost in compliance with children social development at the age of 0 to 3 as proposed by Sujiono (2009). The 
developments include: 1) reacting to other interactions; 2) enjoying interaction with other children; 3) maintaining short time interaction with other children; 4) willingly to share own stuff with others; 5) showcasing petty action to postpone excitement; 6) imitating others' actions; and 7) participating in parallel games.

Single parents' ability in shaping children social development is a result of extended family's assistance and involvement. Without their help, it may be impossible for single parents to provide proper social development as the experts suggest. This is due to lower education background of single parents, who obtain their latest education in elementary/madrasah level.

b) Early Childhood's Emotional Development with Single Parents

From parents' point of view, the success of early childhood's emotional development can be measured using the following criteria: 1) have good emotional control; 2) have empathy to their friends; 3) always happy; 4) crying in the right situation; and 5) share some own stuff with their same-age peers.

In the other hand, Sujiono (2004) suggested children development between the ages of 0 and 3 as follows: 1) cannot tolerate frustration; 2) crying or yelling easily; 3) often unable to control desire; 4) start expressing affection; 5) expecting routines and comfort; 6) begin to feel others' emotion around them; and 7) declaring self-existence, sometimes in an assertive way.

Theories proposed by Sujiono and parents only differ in terms of naming system. For instance, while parents refer to "good emotional control", Sujiono identifies it as "cannot tolerate the frustration". It can be considered natural since from parents' point of view, the uncontrolled outburst of anger represents emotion. Thus, child with stable emotion will not easily get angry.

While parents include crying in a right situation, Sujiono uses crying or yelling easily. In this term, parents' statements are much more reasonable since children who overly cry may possess emotional instability, whether too sensitive or have traumatic experience.

The writer argues that the two theories are similar in terms of their principles. Both indicators of "have empathy to their friends" and "share own stuff with others" are children's ways to express affection to others. As a result, children start to feel other children's emotion, i.e. feel sorry, so that they need to give others some of their stuff such as sweets, toys and cakes.

\section{CONCLUSION}

Parenting style adopted by single parents of Madurese migrant in Sidotopo, Surabaya is greatly affected by lower education and mother's double role as father. As a single parent, a mother becomes a breadwinner as well as a housewife, who is responsible in taking care of her children and household chores. The study found that single parents in the area adopt Democratic as their parenting style, with Informant I using Democratic Authoritarian while Informant II employs Permissive Democratic.

Furthermore, the study found three indicators of early childhood's socio-emotional development. The indicators were: 1) experience temper tantrum once things unfulfilled; 2) willingly share own stuff with others; 3) show confidence when being asked for handshake; and 4) show reciprocal conversation.

\section{ACKNOWLEDGMENT}

The authors would like to thanks the Kampung Sombo community which has cooperated in this research.

\section{REFERENCES}

[1] Bronfenbenner. (2009). The Ecology of Human Development. Harvard: Harvard University Press.

[2] Shochib, Moh. (2010). Pola Asuh Orang Tua Dalam Membantu Anak Mengembangkan Disiplin Diri. Jakarta: Rineka Cipta.

[3] Dagun, SM. (2002). Psikologi keluarga. Jakarta: Rineka

[4] Yusuf, Syamsu. (2004). Psikologi Perkembangan Anak \& Remaja. Bandung: PT. Remaja Rosdakarya.

[5] Hurlock,B.Elizabeth. (1995). Perkembangan Anak. Edisi Keenam. Jakarta: PT. Erlangga.

[6] Santrock, W John. (2007). Perkembangan Anak. Edisi kesebelas. Jilid 2. Jakarta: Erlangga

[7] Sujiono, Nurani Yuliani. (2009). Konsep Dasar Pendidikan Anak Usia Dini. Jakarta: PT. Macanan Jaya Cemerlang. 